\title{
Aperfeiçoamento das habilidades comunicativas em apresentações orais - treinamento de comunicação para universitários
}

\section{RESUMO}

As comunicações orais em sala de aula contemplam conteúdos curriculares e, comumente, têm por público-alvo o docente e a própria turma. Além disso, os eventos técnico-científicos, nos quais se assume a posição de expositor de trabalhos, fazem parte do cotidiano dos universitários. Por isso, a competência de falar em público torna-se um dos determinantes do sucesso profissional. Porém, grande parte das pessoas tem dificuldades de se expor nessas apresentações. A exposição oral é um gênero que deve pressupor um planejamento prévio, no qual se deve demonstrar a capacidade de elaboração de um texto oral relacionado com o tema e o conteúdo de determinada pesquisa, além das habilidades comunicativas para transmitir um conteúdo. A Programação Neurolinguística propõe a possibilidade de programar comportamentos por meio do uso da linguagem, já que a mesma advoga puramente a pragmática, importando-se, primariamente, com a obtenção de resultados, junto com 0 treino das habilidades comunicativas, envolvendo treinamento vocal que é válido para a melhoria da comunicação em exposição oral. Proposição: O objetivo principal deste trabalho foi propor e realizar um programa de treinamento de alta performance em comunicação para desenvolver as habilidades comunicativas em apresentações orais em estudantes de Ensino Superior. Os objetivos específicos foram comparar os resultados pré e pós-intervenção para testar a aplicabilidade do material desenvolvido e a efetividade do treinamento na população estudada. Método: Participaram do estudo, 38 estudantes de Ensino Superior do $1^{\circ}$ Ano de Graduação dos Cursos de Fonoaudiologia, Medicina e Odontologia da Faculdade de Odontologia de Bauru, da Universidade de São Paulo (FOB-USP). Após assinar o termo de consentimento livre e esclarecido, foram submetidos a um treinamento na própria universidade, com metodologias ativas de aprendizagem, intercalando parte teórica e treino prático elaborado pela pesquisadora, no total de oito encontros, com duração de duas horas cada. $\mathrm{Na}$ pré-intervenção e na pós-intervenção, os participantes realizaram uma apresentação para os demais participantes e para uma banca avaliadora formada por três juízes, dois fonoaudiólogos e um psicólogo, momento em que foi avaliado o desempenho nas apresentações orais. Resultados: Observou-se melhora estatisticamente significativa $(<0,05)$ na pós-intervenção em todas as variáveis analisadas, tanto na avaliação realizada pelos juízes, como na autoavaliação. Conclusão: Conclui-se, portanto, que o programa de treinamento apresentado, juntamente com o material elaborado, a apostila "Alta Performance em Comunicação" é efetivo à medida que os universitários, participantes desta pesquisa, melhoraram seu desempenho nas apresentações orais. Palavras-chave: Comunicação - Treinamento da Voz - Fala - Programação Neurolinguística 